\title{
Suvremene uloge žene u obitelji iz perspektive studenata istočne Hrvatske
}

\author{
Mirko Lukaš* \\ mirkolukas64@gmail.com \\ https://orcid.org/0000-0003-2725-3035 \\ Lucija Puhanić** \\ lpuhanic@outlook.com \\ https://orcid.org/0000-0002-6874-0246
}

https://doi.org/10.31192/np.18.2.5

UDK: 305-055.2:303.423-057.87(497.54)

316.36-055.2: 303.423-057.87(497.54)

Prethodno priopćenje / Preliminary communication

Primljeno: 12. svibnja 2020.

Prihvaćeno: 15. lipnja 2020.

Društvene promjene ostavljaju velik utjecaj na obitelj, njezinu strukturu, čimbenike i njihove obiteljske uloge. Suvremena društva doživljavaju ekspanziju žena na tržištu rada, što se reflektira na njihov položaj $i$ ulogu u obitelji. Uz tradicionalnu ulogu domaćice žena preuzima $i$ profesionalnu angažiranost. Ona u obitelji uz financijski doprinos i dalje ostvaruje ulogu majke te brine o djeci i domaćinstvu. Teret većine kućanskih poslova ostao je zadaća žene kao i kod ranijih generacija. Ovo istraživanje je imalo za cilj ispitati stavove studenta istočne Hrvatske o ulogama žene u suvremenoj obitelji. Istraživanjem se nastoji odgovoriti koje su ženine uloge dominantne $i$ u današnjim obiteljima u odnosu na tradicionalnu obitelj. U istraživanju je sudjelovalo 375 studenata (202 sudionika i 173 sudionice) sa Sveučilišta Josipa Jurja Strossmayera u Osijeku. Za provedbu istraživanja korišten je anketni upitnik. Obrada podataka provedena je deskriptivnom statistikom, $t$-testovima za nezavisne uzorke te jednosmjernom analizom varijance. Dobiveni rezultati imaju očekivane stavove u odnosu na ulogu s obzirom na spol i područje studija. Sudionici ispitivanja s društvenih, humanističkih te agrobiotehničkih znanosti pokazuju egalitarnije stavove prema ulogama žene u obitelji od ostalih sudionika.

Ključne riječi: dominantne uloge, egalitarni pogledi, neovisnost, područje studiranja, tradicionalni stavovi, zaposlena žena.

\footnotetext{
* Izv. prof. dr. sc. Mirko Lukaš, Sveučilište Josipa Jurja Strossmayera u Osijek, Filozofski fakultet, Lorenza Jägera 9, HR-31000 Osijek.

*** Lucija Puhanić, mag. educ. engleskog jezika i književnosti i pedagogije, Srednja škola Isidora Kršnjavoga, Augusta Cesarca 20, HR-31500 Našice.
} 


\section{Uvod}

Uloga žene u oblikovanju suvremene obitelji mijenja se pod utjecajem demokratskih i globalnih kretanja društva. Današnja žena više nije samo supruga, majka i domaćica, nego je ona profesionalno angažirana osoba na tržištu rada. Zaposlena žena u obitelji i dalje obnaša brojne često neuskladive obveze uzrokovane rodnim podjelama i očekivanjima.

Obitelj se tradicionalno promatra kao društvena skupina obilježena

»zajedničkim prebivanjem, ekonomskom suradnjom i reprodukcijom. Ona obuhvaća odrasle osobe oba spola od kojih barem dvije održavaju društveno prihvaćenu spolnu vezu, plus jedno ili više djece, vlastite ili usvojene, te odrasle osobe koje seksualno kohabitiraju. «1

Obitelji mogu biti potpune kada ih čine oba roditelja, djeca i drugi članovi, poput djeda, bake, tetke, ujaka, strica i srodnika koji žive zajedno u istom domu, ili nepotpune u kojima nedostaje jedan roditelj. Jednoroditeljske ili obitelji nepotpune strukture uzrokovane su naglim društvenim promjenama, razvodima, ponovnim vjenčanjem, a sve češće rađanjem djece izvan braka.

Tradicionalna nuklearna obitelji obavlja biološko-reproduktivnu funkciju stvaranja potomstva; odgojnu funkciju stjecanja prvih osjetnih zapažanja, iskustva i znanja; društveno-kulturnu funkciju izgrađivanja stavova, pozitivnih odnosa prema drugima te formiranja higijenskih, radnih i kulturnih navika; gospodarsku; moralnu; religijsku i domoljubnu funkciju. ${ }^{2}$

Nikada nije postojao samo jedan oblik obitelji. Uvijek je to bila stvarnost ljudskih socijalnih i ekonomskih odnosa. Odnosi u ljudskom društvu su tijekom povijesti bili vrlo promjenjivi i odražavali su različite funkcije roda i kućanskih grupa u odnosu na društvo. ${ }^{3}$

Suvremena obitelj obuhvaća više toga što nije prototip tradicionalne obitelji. Postoje velika razilaženja oko njezina definiranja, uz pitanje postoji li uopće obitelj ako je polovica para odvojena, ako par nije oženjen, ako su djeca uklonjena ili članovi ne žele živjeti zajedno. ${ }^{4}$ U suvremenoj obitelji često žene i muškarci teže materijalnom blagostanju i profesionalnom napredovanju, a zanemaruju tradicionalne obiteljske vrijednosti, ${ }^{5}$ »što rezultira devolucijom

${ }^{1}$ Usp. Mirko LUKAŠ, Obiteljski odgoj u Hrvatskoj - razvoj ideja od 1850. do 1918. godine, Rijeka, Hrvatsko futurološko društvo, 2010, 22.

${ }^{2}$ Usp. Ante VUKASOVIĆ, Obitelj - vrelo i nositeljica života, Zagreb, Hrvatski katolički zbor MI, 1994, 25-40.

${ }^{3}$ Rosemary Radford RUETHER, Christianity and the Making of the Modern Family, Boston, MA: Unitarističko univerzalističko udruženje kongregacija, 2001.

${ }^{4}$ David POPENE, Disturbing the Nest. Family Change and Decline in Modern Societies, New Brunswick, NJ, Transaction Publishers, 1988, 5

${ }^{5}$ Usp. Dubravka MALEŠ, Obitelj i obiteljski odgoj u suvremenim uvjetima, Dijete, vrtić, obitelj, 67 (2012) 13-15. 
obitelji i njenih funkcija . ${ }^{6}$ Svaka osoba može definirati obitelj na svoj način i u njoj obuhvatiti odnose i obrede koje dijeli s ljudima, pridajući im važnost obiteljskih vrijednosti.?

Demokratski odnosi u obiteljima temelje se na izmijenjenim ulogama i statusu žene, slobodi izbora, afektivnim vezama i načelu poštovanja. Suvremene žene su obrazovane i zaposlene s jednakim pravima, slobodama i obvezama $u$ društvu kao i muškarci. Ipak se još uvijek mnoge žene bore s raspodjelom poslova te $s$ »redefiniranjem obiteljskih uloga.$^{8}$ Redefiniranje uloga zahtijeva izmjenu stavova prema rodnoj ulozi, koja obuhvaća kulturološka i socijalno propisana ponašanja dodijeljena ženama i muškarcima, a temeljena je na rodnim razlikama. ${ }^{9}$ Značenja koja ljudi pripisuju pojedinim poslovima i zanimanjima oblikuju rod pa pojedine vidimo kao »primjerenije « ženama, a druge muškarcima. ${ }^{10}$

Ugovor između partnera koji daju svoj pristanak za formiranje potpuno nove zajednice potvrđene od strane Crkve i/ili države nazivamo brak. U njemu žena preuzima ulogu supruge. ${ }^{11}$ Brak kao zajednica života žene i muškarca u ljudskoj povijesti je shvaćen kao specifična institucija koja proizlazi iz ljudske naravi, a ne iz arbitrarne ljudske odredbe. ${ }^{12}$ On »osigurava međusobnu pripadnost, pažnju, utočište, podršku, ljubav, razumijevanje, individualni i zajednički životni i profesionalni razvoj «. ${ }^{13}$ Bračni su partneri dužni jedan drugome biti vjerni, međusobno se poštovati, uzajamno se pomagati i uzdržavati, te održavati skladne bračne i obiteljske odnose. Oni zajedno odlučuju o rađanju i podizanju djece te obavljanju poslova. ${ }^{14}$

Brak podrazumijeva zajedničku aktivnost na svim poslovima u jednom domaćinstvu, od planiranja obitelji i djece, njihova odgoja, ekonomije, bavljenja i napredovanja u profesiji, razvijanju zajedničkih interesa partnera do bavljenja sportskim, kulturnim i društvenim aktivnostima. ${ }^{15}$ Stoga je za doživljaj bračne kvalitete važnija percepcija partnera o pravednoj raspodjeli, nego sama raspodjela poslova. ${ }^{16}$

${ }^{6}$ Usp. Sandra KRAMARIĆ, Obitelj i roditeljstvo u suvremenom društvu, u: Tihana KOKANOVIĆ, Siniša OPIĆ, Anka JURČEVIĆ LOZANČIĆ (ur.), Međunarodni znanstveno-stručni skup. Sadašnjost za budućnost odgoja i obrazovanja - mogućnosti i izazovi, 2017, 204-209.

7 Usp. Melissa MAYNTZ, Definitions of Family, https://family.lovetoknow.com/definition-family (19.06.2020).

${ }^{8}$ Usp. Maja LJUBETIĆ, Biti kompetentan roditelj, Zagreb, Mali profesor, 2007, 20.

${ }^{9}$ Usp. Andreja BARTOLAC, Željka KAMENOV, Olivera PETRAK, Rodne razlike u obiteljskim ulogama, zadovoljstvu i doživljaju pravednosti s obzirom na tradicionalnost stava, Revija za socijalnu politiku, 18 (2011) 175-194, https://doi.org/10.3935/rsp.v18i2.998.

${ }^{10}$ Usp. Branka GALIĆ, Žene i rad u suvremenom društvu - značaj »orodnjenog « rada, Sociologija i prostor, 49 (2011) 189, 25-48, https://doi.org/10.5673/sip.49.1.2.

${ }^{11}$ Usp. Ljubetić, Biti kompetentan roditelj..., 8.

${ }^{12}$ Usp. Ivan BUBALO, Brak i obitelj u promijenjenom društveno-kulturnom kontekstu, Bogoslovska smotra, 85 (2015) 3, 647-664.

${ }^{13}$ Usp. Marko STEVANOVIĆ, Obiteljska pedagogija, Varaždinske Toplice, Tonimir, 2000, 52.

${ }^{14}$ Usp. Obiteljski zakon, Narodne novine, 103/2015.

${ }^{15}$ Usp. Stevanović, Obiteljska pedagogija ..., 52-53.

${ }^{16}$ Usp. Mira ČUDINA-OBRADOVIĆ, Josip OBRADOVIĆ, Psihologija braka i obitelji, Zagreb, Golden marketing - Tehnička knjiga, 2006, 134. 


\section{Položaj žene u suvremenoj obitelji}

Tijekom 19. i 20. stoljeća pod utjecajem industrijalizacije i građanskih revolucija nastaje »demokratski tip porodice« u kojem muškarac i žena u braku imaju jednaka prava i dužnosti. Novi ekonomski odnosi traže uključivanje žena u proces rada izvan kuće, što rezultira smanjenjem autoriteta muškarca. ${ }^{17}$

»Posao domaćice i briga o kućanstvu, djeci i starijim članovima obitelji mnogim je ženama bio stalni posao. Većina poslova ostaje odgovornost žena i u razvijenim društvima 21. stoljeća, ali se od nje očekuje preuzimanje i mnogih dodatnih uloga. $\ll^{18}$

Skup aktivnosti njege, zaštite i odgoja djece koje majka obavlja nazivaju se »majčinska praksa«. Ona proizlazi iz »neodgodivih potreba djeteta i ne obuhvaća samo određene vještine i znanja, nego i uspostavljanje dubokog emocionalnog odnosa nužnog za razvoj osjećaja, sigurnosti i budućih društvenih i kognitivnih kompetencija djeteta «. ${ }^{19}$ Iz takvoga okruženja je dijete osposobljeno za samostalan život i ono uspješnije »presijeca psihološku pupčanu vrpcu s majkom ${ }^{20}{ }^{20}$

Suvremeno društvo je iznjedrilo pojavu »intenzivnog majčinstva« koje počiva na uvjerenju da djeca trebaju stalnu skrb svojih bioloških majki. Žena stoga ostavlja sve obveze posvećujući se djetetu. Ovaj pristup majčinstvu je iscrpljujući, a žene koje ne uspiju zadovoljiti postavljene standarde smatraju sebe lošima. ${ }^{21} »$ Da bi bila učinkovit roditelj, žena ne mora biti 'all mother', već mora prepoznavati važnost i odvojiti svoje potrebe od majčinskih. $\ll^{22}$

Najpoželjniji ideal ženske uloge u društvu i dalje je majčinstvo i briga za djecu, muža i kuću. ${ }^{23}$ Međutim, kod žena se sve više zamjećuje sklonost odustajanja od majčinstva kao središnjeg životnog cilja. Istraživanja pokazuju da je »zaposlenost ženama u Hrvatskoj izvor zadovoljstva i ostvarenja karijere« kod $58,9 \%$ sudionica, dok je majčinstvo izvor zadovoljstva tek za njih $43 \%{ }^{24}$

\footnotetext{
${ }^{17}$ Usp. Lidija VASILJEVIĆ, Feminističke kritike pitanje braka, porodice i roditeljstva, u: Adrijana ZAHARIJEVIĆ (prir.), Neko je rekao feminizam?, Novi Sad, Heinrich-Böll-Stiftung, Artprint, 2012, 94-119.

${ }^{18}$ Usp. Agnes SIMONYI, Ravnoteža između posla i života te važnost ustanova za djecu, Djeca u Europi, 3 (2011) 5, 24-25.

${ }^{19}$ Usp. Čudina-Obradović, Obradović, Psihologija braka..., 256.

${ }^{20}$ Usp. Marijan KOŠIČEK, Antiroditelj, Sarajevo, Svjetlost, 1990, 15.

${ }^{21}$ Usp. Barbara KUŠEVIĆ, Kultura intenzivnog majčinstva kao izazov za suvremenu pedagogiju, u: Maja LJUBETIĆ, Smiljana ZRILIĆ (ur.), Kultura kao polje pedagoške akcije. Odgoj, obrazovanje, kurikulum, Zagreb, Hrvatsko pedagogijsko društvo, 2013, 98-106.

${ }^{22}$ Usp. isto, 104.

${ }^{23}$ Usp. Branka GALIĆ, Seksistički diskurs rodnog identiteta, Socijalna ekologija, 13 (2004) 3-4, 305-324.

${ }^{24}$ Usp. Krunoslav NIKODEM, Branka GALIĆ, Percepcija rodnih jednakosti i šansi pri zapošljavanju u hrvatskom društvu. Pogled nezaposlenih žena, Revija za socijalnu politiku, 16 (2009) 3, 253-270; https://doi.org/10.3935/rsp.v16i3.855.
} 
Žena može obavljati dva tipa posla, nevidljivi neplaćeni rad u obitelji (rađanje, kućanski poslovi, briga za članove obitelji i sl.) i plaćeni posao izvan obitelji. Neplaćeni posao rijetko donosi samopotvrđivanje, društveno priznanje ili mogućnost napredovanja. ${ }^{25}$ Ali zato, nezaposlene majke mogu provoditi više vremena u društvu sa svojom djecom kuhajući, čisteći ili obavljajući ostale kućanske poslove. Zaposlene majke provode manje vremena s djecom, ali je to njihovo zajednički provedeno vrijeme često kvalitetnije. Majke svojoj djeci čitaju, pomažu u pisanju zadaća, igraju se s njima, a to pozitivno utječe na njihov razvoj. ${ }^{26}$

Roditeljstvo je izrazito odgovorna i zahtjevna životna uloga koja uključuje više aktivnosti odraslih osoba koje skrbe o podizanju djece i »uključuje vještu i kreativnu uporabu znanja, iskustava i metoda « o odgoju ${ }^{27}$ Tradicionalno se roditeljstvo izjednačava $\mathrm{s}$ ulogom majčinstva, dok ga suvremeni pristup shvaća kao »ravnopravno partnerstvo . $^{28}$ Suvremeni se roditelji suočavaju sa zahtjevima radnog mjesta koji su često u sukobu s obiteljskima, sa svojom nemogućnošću pružanja adekvatne skrbi i s različitim potrebama djece. ${ }^{29}$ Zajedničkim roditeljstvom izbjegavaju se nepovoljni obiteljski odnosi nastali uslijed opterećenosti majke ili isključenosti oca jer žene znaju odnos muškarca i djece promatrati kao djelo ljubavi i brige i prema njima samima. ${ }^{30}$

Istraživanja pokazuju da očevi provode manje od jednog sata ili 54 minute na dan s djecom u aktivnostima hranjenja, kupanja, čuvanja i sl., ${ }^{31}$ dok majke provode 5,2 do 10,7 sati. $^{32}$ Suvremena žena obavlja i dalje tradicionalno ženske poslove, ali i dio obveza koje se smatraju muškima, poput određivanja džeparaca, discipliniranja i vođenja brige s kim djeca izlaze. ${ }^{33} \mathrm{U}$ obiteljima bez veće angažiranosti muževa u obavljanju kućanskih poslova ženu nakon plaćenog radnog vremena čeka »druga smjena«. ${ }^{34}$

${ }^{25}$ Usp. Lynette ŠIKIĆ-MIĆANOVIĆ, Some conceptualisations and meanings of domestic labour, Društvena istraživanja, 10 (2001) 4-5, 731-766.

${ }^{26}$ Usp. Amy HSIN, Christina FELFE, When Does Time Matter? Maternal Employment, Children's Time With Parents, and Child Development, Demography, 51 (2014) 1867-1894; doi:10.1007/ s13524-014-0334-5.

${ }^{27}$ Usp. Ljubetić, Biti kompetentan..., 45.

${ }^{28}$ Usp. Cudina-Obradović, Obradović, Psihologija braka..., 264.

${ }^{29}$ Usp. Ljubetić, Biti kompetentan..., 58.

${ }^{30}$ Usp. Rachel LEVY-SHIFF, Individual and contextual correlates of marital change across the transition to parenthood, Developmental Psychology. 30 (1994) 4, 591-601, doi:10.1037/00121649.30.4.591

${ }^{31}$ Usp. Ursula HENZ, Fathers' involvement with their children in the United Kingdom: Recent trends and class differences, Demographic Research, 40 (2019) 30, 865-896; doi:10.4054/ DemRes.2019.40.30.

${ }^{32}$ Usp. Ivana JUGOVIĆ, Željka KAMNEOV, Rodna (ne)ravnopravnost i diskriminacija u obiteljskim odnosima, u: Željka KAMENOV, Branka GALIĆ (ur.), Rodna ravnopravnost i diskriminacija u Hrvatskoj, Zagreb, Ured za ravnopravnost spolova Vlade RH, 2011, 28-38.

${ }^{33}$ Usp. isto, 32.

${ }^{34}$ Usp. Davor TOPOLČIĆ, Muškarci to ne rade. Rodno segregirana podjela rada u obitelji, Društvena istraživanja, 10 (2001) 4-5, 767-789. 


\section{Metodološki pristup}

Cilj ovoga istraživanja je utvrđivanje stavova studenata istočne Hrvatske o ulozi žene u suvremenoj obitelji. Zadaće istraživanja su: 1. Utvrditi sociodemografske pokazatelje sudionika, obrazovanje majki sudionika, status zaposlenosti majki i njezin financijski doprinos kućanstvu. 2. Utvrditi stavove sudionika o položaju žene i njezinim ulogama s obzirom na njihov spol, fakultet i geografsko porijeklo. 3. Analizirati razlike u stavovima o ulogama žene u obitelji s obzirom na obrazovanje majke, status zaposlenosti majke, financijski doprinos i provođenje slobodnog vremena majke.

Hipoteze istraživanja:

H1: Očekuju se statistički značajne razlike među sudionicima ispitivanja s obzirom na spol, geografsko porijeklo i fakultet koji pohađaju.

H2: Očekuju se pozitivni stavovi sudionika iz urbanih područja i sudionika koji pohađaju društvene studije o ulogama žene u obitelji.

H3: Očekuju se tradicionalni stavovi sudionika s agrobiotehničkih znanosti i fakulteta elektrotehnike, računarstva i informacijskih tehnologija za razliku od sudionika koji pohađaju društvene i humanističke znanosti kod kojih se očekuju egalitarni stavovi.

Za provedbu istraživanja izrađen je anketni upitnik podijeljen u dva dijela. Prvi dio sadrži 11 pitanja o socio-demografskim pokazateljima, dok se drugi dio odnosi na 21 tvrdnju o položaju i ulozi žene u obitelji. Većina tvrdnji iz upitnika sastavljena je posebno za ovo istraživanje, a pojedine tvrdnje temelje se na prethodnim istraživanjima ${ }^{35}$ uz izmjene tvrdnji sukladno cilju ovoga istraživanja i mogućnost njihovih usporedbi s navedenim izvorima. Stavovi su mjereni na Likertovoj skali od 5 stupnjeva gdje 1 označava - uopće se ne slažem, 2 - ne slažem se, 3 - niti se slažem niti se ne slažem, 4 - uglavnom se slažem i 5 - u potpunosti se slažem. Dobiveni podatci obrađeni su pomoću statističkog programa za računalnu obradu podataka (SPSS) postupcima deskriptivne statistike. Korišten je t-test za nezavisne uzorke pri utvrđivanju razlika u stavovima i analiza varijance, kao i Games-Howell post hoc test za utvrđivanje značajnosti razlike u stavovima.

U istraživanju je sudjelovalo 375 studenata Sveučilišta Josipa Jurja Strossmayera u Osijeku, 202 sudionika ili $54 \%$ i 173 sudionice ili $46 \%$. Broj sudionika s Građevinskog fakulteta je 93 ili $25 \%$ (M=50 i $\check{Z}=43)$, s Filozofskog fakulteta 94 ili $25 \%$ (M=22 i $\check{Z}=72)$, s Fakulteta agrobiotehničkih znanosti 94 ili

\footnotetext{
${ }^{35}$ Usp. Gordan ČRPIĆ, Željka BIŠĆAN, Muško i žensko između uloge i osobe. Ispitivanje promjene uloga spolova u hrvatskom društvu, Bogoslovska smotra, 70 (2000) 2, 421-442; Kristin DONNELLY i sur., Attitudes Toward Women's Work and Family Roles in the United States, 1976-2013, Psychology of Women Quarterly, 40 (2015) 1, 41-54; https://doi. org/10.1177/0361684315590774.
} 
25 \% (M=48 i $\check{Z}=46)$, s Fakulteta elektrotehnike, računarstva i informacijskih tehnologija 94 ili 25 \% (M=82 i $\check{Z}=12)$. Sudionici su studenti od prve godine preddiplomskih studija do druge godine diplomskih studija u dobi od 19 do 27 godina.

\section{Rezultati istraživanja}

Socio-demografska obilježja sudionika pokazuju da od ukupnog broja 375 studenata na selu živi 169 ili 45,1 \%, a 206 ili 54,9 \% ih živi u gradu. Najveći broj majki sudionika istraživanja, njih 253 ili 67,5 \% ima završenu srednju školu. Ostali pokazatelji obrazovanja majki vidljivi su u tablici 1. Broj stalno zaposlenih majki je 238 ili 63,5\%, a 84 ili 22,4 \% majke su domaćice.

Slobodno vrijeme majke sudionika 70,7 \% najčešće provode kod kuće, a 9,1 $\%$ sudionika tvrdi da njihovim majkama ne preostaje slobodnog vremena. Sudionici procjenjuju da majke u 49,3 \% slučajeva financijski doprinose njihovoj obitelji podjednako kao i očevi.

Zbog preglednije analize izjave sudionika su objedinjene u četiri područja koja se zatim grupiraju u dvije skupine. Prvu čine tvrdnje o ulogama žene u obitelji »žena majka i domaćica« $\mathrm{i}$ »žena poslovna osoba«, drugu skupinu čine tvrdnje o položaju žene u obitelji »ravnopravnost žene i muškarca u obitelji« i »dominantnost žene u obitelji«.

Tablica 1. Stupanj obrazovanja i zaposlenost majki sudionika

\begin{tabular}{|c|c|c|c|c|c|}
\hline $\begin{array}{c}\text { Obrazovanje } \\
\text { majki }\end{array}$ & $\mathbf{N}$ & $\mathbf{\%}$ & Zaposlenost majke & $\mathbf{N}$ & $\mathbf{\%}$ \\
\hline Osnovna škola & 28 & 7,5 & Zaposlena & 238 & 63,5 \\
\hline Srednja škola & 253 & 67,5 & Nezaposlena & 21 & 5,6 \\
\hline Viša škola & 20 & 5,3 & Domaćica & 84 & 22,4 \\
\hline Visoka škola & 36 & 9,6 & Umirovljenica & 22 & 5,9 \\
\hline Magisterij, doktorat & 38 & 10,1 & $\begin{array}{c}\text { Sezonski posao } \\
\text { Vlasnica obrta }\end{array}$ & 4 & 1,1 \\
Ukupno & 375 & 100 & $\begin{array}{c}\text { Ukupno } \\
1,6\end{array}$ \\
\hline
\end{tabular}

U tablici 2 vidljivi su stavovi sudionika o ulogama žene u obitelji u kojima oni izražavaju $M=4,31$ egalitarne stavove iskazujući mišljenje o ravnopravnosti žena i muškaraca. Sudionici istraživanja doživljavaju ženu kao poslovnu osobu $\mathrm{M}=3,48$ usmjerenu na uspjeh i karijeru, a ne samo okrenutu na ulogu domaćice $\mathrm{M}=3,21$ kojoj je briga za dijete i obitelj glavna zadaća. Sudionici ne smatraju ženin položaj $M=2,61$ dominantnim u obitelji. 
Tablica 2. Stavovi o ulogama žene u obitelji

\begin{tabular}{|l|c|c|}
\hline \multicolumn{1}{|c|}{ Varijable } & M & SD \\
\hline Ravnopravna žena u obitelji & 4,31 & 0,68 \\
\hline Poslovna žena & 3,48 & 0,52 \\
\hline Žena majka i domaćica & 3,21 & 0,55 \\
\hline Dominantna osoba u obitelji & 2,61 & 0,66 \\
\hline
\end{tabular}

Stavovi o položaju muškarca i žene u obitelji vidljivi su u tablici 3. Uglavnom ili u potpunosti se sudionici istraživanja slažu 86,9 \% s tvrdnjom: »Muškarac i žena trebali bi financijski pridonositi kućanstvu«. Sudionici se u 331 ili 88,2 \% slučajeva slažu s tvrdnjom »Muškarci i žene zajednički dijele kućanske polove i skrbe o djeci.« S tvrdnjom: »U donošenju odluka ravnopravno sudjeluju i žene i muškarci« sudionici se uglavnom ili u potpunosti slažu 73,6 \%.

Tablica 3. Ravnopravnost i položaj žene u obitelji

\begin{tabular}{|l|c|c|c|c|c|}
\hline \multicolumn{1}{|c|}{ Tvrdnje } & $\begin{array}{c}\text { Uopće } \\
\text { se ne } \\
\text { slažem }\end{array}$ & $\begin{array}{c}\text { Uglavnom } \\
\text { se ne } \\
\text { slažem }\end{array}$ & $\begin{array}{c}\text { Niti se } \\
\text { slažem } \\
\text { niti se ne } \\
\text { slažem }\end{array}$ & $\begin{array}{c}\text { Uglavnom } \\
\text { se slažem }\end{array}$ & $\begin{array}{c}\text { U } \\
\text { potpunosti } \\
\text { se slažem }\end{array}$ \\
\hline $\begin{array}{l}\text { Muškarac i žena trebali } \\
\text { bi financijski pridonositi } \\
\text { kućanstvu. }\end{array}$ & $2,1 \%$ & $1,6 \%$ & $9,3 \%$ & $26,4 \%$ & $60,5 \%$ \\
\hline $\begin{array}{l}\text { Muškarci i žene zajednički } \\
\text { dijele kućanske poslove i } \\
\text { skrbe o djeci. }\end{array}$ & $2,7 \%$ & $3,7 \%$ & $5,3 \%$ & $19,7 \%$ & $68,5 \%$ \\
\hline $\begin{array}{l}\text { U donošenju odluka } \\
\text { ravnopravno sudjeluju i žene i } \\
\text { muškarci. }\end{array}$ & $1,9 \%$ & $7,7 \%$ & $16,8 \%$ & $31,7 \%$ & $41,9 \%$ \\
\hline
\end{tabular}

U tablici 4 vidljivi su rezultati o ulozi žene kao zaposlene osobe u kojima dominira $72 \%$ mišljenje sudionika da je »zaposlenje najbolji način da žena postane slobodna « i neovisna osoba. Svoje slaganje s tvrdnjom: »Zaposlena majka može uspostaviti topao i prisan odnos s djecom« iskazuje 325 ili 86,6 \% sudionika. Tvrdnju: »U redu je ako se žena odluči ubrzo nakon poroda vratiti na posao« podržava $68,6 \%$ sudionika. S tvrdnjom: »Predškolsko dijete emocionalno više pati ako majka radi« ne slažu se $50,2 \%$ sudionika, a $30,4 \%$ niti se slaže niti se ne slaže. Međutim, 48,8 \% sudionika ima stajalište: "Za dijete je bolje ako je majka u prve dvije godine kod kuće«, dok 36 \% ne može odrediti svoje stajalište.

Ispitujući stavove o ulozi žene kao majke i domaćice obitelji uočavaju se 52 \% sudionika koji tvrde da se uopće ne slažu ili uglavnom se ne slažu s tvrdnjom: »Većina žena zapravo želi samo djecu i obitelj«, dok je 37 \% sudionika neodlučno. Tvrdnju: »Posao domaćice ispunjava kao i bilo koji drugi posao « zastupa $42,4 \%$ sudionika. Dominantna uloga žene za $72,5 \%$ sudionika je u slučaju njege 
Tablica 4. Uloga žene kao poslovne osobe u postotcima

\begin{tabular}{|l|c|c|c|c|c|}
\hline \multicolumn{1}{|c|}{ Tvrdnje } & $\begin{array}{c}\text { Uopće } \\
\text { se ne } \\
\text { slažem }\end{array}$ & $\begin{array}{c}\text { Uglavnom } \\
\text { se ne } \\
\text { slažem }\end{array}$ & $\begin{array}{c}\text { Niti se } \\
\text { slažem } \\
\text { niti se ne } \\
\text { slažem }\end{array}$ & $\begin{array}{c}\text { Uglavnom } \\
\text { se slažem }\end{array}$ & $\begin{array}{c}\text { U } \\
\text { potpunosti } \\
\text { se slažem }\end{array}$ \\
\hline $\begin{array}{l}\text { Zaposlenje je najbolji način da } \\
\text { žena postane slobodna }\end{array}$ & 2,4 & 7,5 & 18,1 & 46,7 & 25,3 \\
\hline $\begin{array}{l}\text { Zaposlena majka može } \\
\text { uspostaviti topao i prisan } \\
\text { odnos s djecom }\end{array}$ & 1,9 & 2,7 & 8,8 & 29,3 & 57,3 \\
\hline $\begin{array}{l}\text { U redu je ako se žena nakon } \\
\text { poroda odluči brzo se vratiti } \\
\text { na posao }\end{array}$ & 4,0 & 7,7 & 19,7 & 28,3 & 40,3 \\
\hline $\begin{array}{l}\text { Predškolsko dijete } \\
\text { emocionalno više pati ako } \\
\text { majka radi }\end{array}$ & 25,1 & 25,1 & 30,4 & 13,6 & 5,9 \\
\hline $\begin{array}{l}\text { Za dijete je bolje ako je majka } \\
\text { u njegove prve dvije godine } \\
\text { kod kuće }\end{array}$ & 5,3 & 9,9 & 36 & 37,3 & 11,5 \\
\hline
\end{tabular}

bolesnog djeteta. Zamijećen je velik postotak sudionika 336 ili 89,6 \% koji tvrde: "Nezaposlena majka može uspostaviti topao i prisan odnos sa svojom djecom." Zapaža se neutralan stav 45,9 \% sudionika koji niti se slažu, niti se ne slažu s tvrdnjom: »Žene bi radije bile kod kuće i pomagale djeci u školskim obvezama.« Ostali pokazatelji vidljivi su u tablici 5.

Tablica 5. Uloga žene kao majke i domaćice u postotcima

\begin{tabular}{|l|c|c|c|c|c|}
\hline \multicolumn{1}{|c|}{ Tvrdnje } & $\begin{array}{c}\text { Uopće } \\
\text { se ne } \\
\text { slažem }\end{array}$ & $\begin{array}{c}\text { Uglavnom } \\
\text { se ne } \\
\text { slažem }\end{array}$ & $\begin{array}{c}\text { Niti se } \\
\text { slažem } \\
\text { niti se ne } \\
\text { slažem }\end{array}$ & $\begin{array}{c}\text { Uglavnom } \\
\text { se slažem }\end{array}$ & $\begin{array}{c}\text { U } \\
\text { potpunosti } \\
\text { se slažem }\end{array}$ \\
\hline $\begin{array}{l}\text { Većina žena zapravo želi samo } \\
\text { djecu i obitelj }\end{array}$ & 19,7 & 32,3 & 37 & 8,3 & 2,7 \\
\hline $\begin{array}{l}\text { Posao domaćice ispunjava kao } \\
\text { i bilo koji drugi posao }\end{array}$ & 8,5 & 19,7 & 29,3 & 28,3 & 14,1 \\
\hline $\begin{array}{l}\text { Njegu bolesnog djeteta } \\
\text { najčešć preuzima majka }\end{array}$ & 5,9 & 5,9 & 15,7 & 44,8 & 27,7 \\
\hline $\begin{array}{l}\text { Nezaposlena majka može } \\
\text { uspostaviti topao i prisan } \\
\text { odnos s djecom }\end{array}$ & 1,3 & 1,1 & 8 & 23,7 & 65,9 \\
\hline $\begin{array}{l}\text { Žene bi radije bile kod kuće } \\
\text { i pomagale djeci u školskim } \\
\text { obvezama }\end{array}$ & 14,9 & 16,3 & 45,9 & 17,9 & 5,1 \\
\hline
\end{tabular}


Istraživanjem se nastojalo dobiti stavove ispitanika o dominaciji ženine uloge u donošenjima različitih obiteljskih odluka, a pokazatelji su vidljivi u tablici 6. Sudionici u 44,5 \% uopće se ne slažu ili uglavnom se ne slažu s tvrdnjom: »Odluka o mjestu zajedničkog prebivališta pripada ženi« nakon vjenčanja mladog para. Odgovor na ovo pitanje ne može dati $43,7 \%$ sudionika koji niti se slaže niti se ne slaže s tvrdnjom. Vrlo provokativna tvrdnja: »Žene imaju završnu riječ u izboru marke obiteljskog automobila« upućuje na procjene sudionika od $64,8 \%$ koji se ne slaže s ovom tvrdnjom.

Sudionici pretežito pokazuju neutralan stav $46,4 \%$ o dominantnom položaju žene u donošenju odluke »O obliku provođenja godišnjih odmora« koju najčešće donosi žena, a oni koji se odlučuju iskazati stav 32,6 \% uglavnom ili u potpunosti se slaže s tvrdnjom. Patrijarhalan stav zamijećen je u 52 \% sudionika koji tvrde da se uopće ili uglavnom ne slažu da »u izboru zanimanja/škole njihove djece majka ima najvažniju odluku«. Svoj stav o ovoj tvrdnji nema 34,4 $\%$ sudionika.

Neutralne tvrdnje mogu ukazivati na demokratske stavove u pogledima sudionika na uloge žene u obitelji ili se pojedini odgovori mogu promatrati i kao ostatci patrijarhalnog odgoja u kojem su važne životne odluke pridržane ocu obitelji.

Tablica 6. Dominantnost žene i njezinih odluka u obitelji

\begin{tabular}{|l|c|c|c|c|c|}
\hline \multicolumn{1}{|c|}{ Tvrdnje } & $\begin{array}{c}\text { Uopće } \\
\text { se ne } \\
\text { slažem }\end{array}$ & $\begin{array}{c}\text { Uglavnom } \\
\text { se ne } \\
\text { slažem }\end{array}$ & $\begin{array}{c}\text { Niti se } \\
\text { slažem } \\
\text { niti se ne } \\
\text { slažem }\end{array}$ & $\begin{array}{c}\text { Uglavnom } \\
\text { se slažem }\end{array}$ & $\begin{array}{c}\text { U } \\
\text { potpunosti } \\
\text { se slažem }\end{array}$ \\
\hline $\begin{array}{l}\text { Odluka o mjestu zajedničkog } \\
\text { prebivališta pripada ženi }\end{array}$ & 20,5 & 24 & 43,7 & 7,7 & 4 \\
\hline $\begin{array}{l}\text { Žene maju završnu riječ u } \\
\text { izboru marke obiteljskog } \\
\text { automobila }\end{array}$ & 33,3 & 31,5 & 29,9 & 2,4 & 2,9 \\
\hline $\begin{array}{l}\text { O obliku godišnjih odmora } \\
\text { najčešce odluku donosi žena }\end{array}$ & 6,9 & 13,9 & 46,4 & 24,8 & 8 \\
\hline $\begin{array}{l}\text { U izboru zanimanja/škole } \\
\text { djece majka ima najvažniju } \\
\text { odluku }\end{array}$ & 29,9 & 22,1 & 34,4 & 9,1 & 4 \\
\hline
\end{tabular}

Iz tablice 7 je vidljivo da postoji statistički značajna razlika među sudionicima $(M=3,29 ; S D=, 54)$ i sudionicama $(M=3,11 ; S D=, 54)$ u stavovima o ženi majci i domaćici $(t=3,27, \mathrm{df}=373, \mathrm{p}<0,001)$. Rezultati ukazuju da sudionici ženu u obitelji doživljavaju kao majku i domaćicu više nego sudionice. Utvrđeno je postojanje statistički značajne razlike između sudionika $(\mathrm{M}=4,14, \mathrm{SD}=, 76)$ i sudionica $(\mathrm{M}=4,51, \mathrm{SD}=, 51 ; \mathrm{t}=-5,481, \mathrm{df}=373, \mathrm{p}<0,001)$ prema stavu o ravnopravnosti u kojem sudionice imaju pozitivnije stavove prema ravnopravnom položaju žene u obitelji nego sudionici. 
Tablica 7. T-test za utvrđivanje razlika u stavovima o položaju žene i njezinim ulogama s obzirom na spol sudionika istraživanja

\begin{tabular}{|c|c|c|c|c|c|c|}
\hline Varijable & Spol & $\mathbf{M}$ & SD & $\mathbf{t}$ & Df & $\begin{array}{c}\text { Sig. } \\
\text { (2-tailed) }\end{array}$ \\
\hline Žena kao majka i domaćica & $\begin{array}{l}\mathrm{M} \\
\check{Z}\end{array}$ & $\begin{array}{l}3,29 \\
3,11\end{array}$ & $\begin{array}{l}0,54 \\
0,54\end{array}$ & $3,27^{* * * \%}$ & 373 & 0,001 \\
\hline Žena kao poslovna osoba & $\begin{array}{l}M \\
\check{Z}\end{array}$ & $\begin{array}{l}2,59 \\
2,62\end{array}$ & $\begin{array}{l}0,64 \\
0,67\end{array}$ & $-0,29$ & 373 & 0,775 \\
\hline \multirow{2}{*}{ Ravnopravnost žene u obitelji } & $\mathrm{M}$ & 4,14 & 0,76 & \multirow{2}{*}{$-5,481^{* * * * *}$} & \multirow{2}{*}{373} & \multirow{2}{*}{0,000} \\
\hline & $\check{Z}$ & 4,51 & 0,51 & & & \\
\hline \multirow{2}{*}{ Dominantnost ženinih odluka } & $\mathrm{M}$ & 2,59 & 0,64 & \multirow{2}{*}{$-0,29$} & \multirow{2}{*}{373} & \multirow{2}{*}{0,775} \\
\hline & $\check{Z}$ & 2,62 & 0,68 & & & \\
\hline
\end{tabular}

$p<0.05^{*}, p<0.01^{* *}, p<0.001^{* * * *}$

Levenovim testom homogenosti varijance je provjerena zadovoljenost preduvjeta homogenosti. Pokazalo se da su varijance varijabli koje su korištene $u$ istraživanju homogene ( $p>0,05)$, osim varijable Ravnopravnost žene u obitelji $\mathrm{F}(3,371)=3,304, \mathrm{p}<0,05$. Transformacija dobivenih podataka (Welch, BrownForsythe) nije promijenila zaključak provedene jednosmjerne analize varijance pa se zaključuje da postoji razlika u stavovima sudionika s obzirom na fakultete koji pohađaju.

Jednosmjernom analizom varijance nije utvrđena statistički značajna razlika u stavu da je ženi najvažnija uloga briga za dijete i obitelj s obzirom na područje studija sudionika $[\mathrm{F}(3,371)=1,820, \mathrm{p}=, 143]$, ali je utvrđena statistički značajna razlika $(\mathrm{p}<0,05)$ u stavovima koji se odnose na ženu kao poslovnu osobu $[\mathrm{F}(3,371)=3,067, \mathrm{p}=, 028]$ s obzirom na fakultet koji pohađaju sudionici. Analizom varijance je utvrđena statistički značajna razlika $(\mathrm{p}>0,01)$ u stavovima prema ravnopravnosti žena u obitelji $[\mathrm{F}(3,371)=3,911, \mathrm{p}=, 009] \mathrm{s}$ obzirom na fakultet sudionika. Značajna je razlika $(\mathrm{p}<0,05)$ utvrđena i u stavovima prema dominantnosti žene u obitelji s obzirom na fakultet sudionika $[\mathrm{F}(3,371)=3,067$, $\mathrm{p}=, 028]$. Razlike u stavovima vidljive su u tablici 8.

Tablica 8. Stavovi o ulogama žene s obzirom na područje studiranja sudionika

\begin{tabular}{|c|c|c|c|c|c|c|}
\hline Varijable & & Ss & Df & MS & $\mathbf{F}$ & Sig. \\
\hline \multirow{2}{*}{$\begin{array}{l}\text { Žena kao majka i } \\
\text { njegovateljica }\end{array}$} & \multirow{2}{*}{ fakultet } & 1,628 & 3 & 0,543 & \multirow{2}{*}{1,820} & \multirow{2}{*}{0,143} \\
\hline & & 110,639 & 371 & 0,298 & & \\
\hline \multirow{2}{*}{ Žena kao poslovna osoba } & \multirow{2}{*}{ fakultet } & 3,903 & 3 & 1,301 & \multirow{2}{*}{3,067} & \multirow{2}{*}{$0,028 *$} \\
\hline & & 157,393 & 371 & 0,424 & & \\
\hline \multirow{2}{*}{$\begin{array}{l}\text { Ravnopravnost žene u } \\
\text { obitelji }\end{array}$} & \multirow{2}{*}{ fakultet } & 5,257 & 3 & 1,752 & \multirow{2}{*}{3,911} & \multirow{2}{*}{$0,009^{* * *}$} \\
\hline & & 166,224 & 371 & 0,448 & & \\
\hline $\begin{array}{l}\text { Dominantnost ženinih } \\
\text { odluka }\end{array}$ & fakultet & $\begin{array}{c}3,903 \\
157,393\end{array}$ & $\begin{array}{c}3 \\
371\end{array}$ & $\begin{array}{l}1,301 \\
0,424\end{array}$ & 3,067 & $0,028^{*}$ \\
\hline
\end{tabular}

$p<0,05^{*}, p<0,01^{* * * *}, p<0,001^{* * * * *}$ 
Games-Howellovim post hoc testom je utvrđeno postojanje značajne razlike u stavovima sudionika prema ulozi žene kao poslovne osobe između onih koji pohađaju Agrobiotehnički fakultet $(M=2,72)$ i Građevinski fakultet $(M=2,44)$. Rezultati sugeriraju da sudionici Agrobiotehničkog fakulteta imaju pozitivnije stavove prema ženi kao poslovnoj osobi u odnosu na sudionike koji dolaze $\mathrm{s}$ Građevinskog fakulteta (tablica 9).

Utvrđeno je postojanje statistički značajne razlike u stavovima prema ravnopravnosti žene u obitelji između sudionika Elektrotehničkog fakulteta $(M=4,13)$ i sudionika Filozofskog fakulteta $(M=4,45)$. Sudionici Filozofskog fakulteta imaju pozitivnije stavove o ravnopravnom položaju žene u obitelji u odnosu na sudionike s Elektrotehničkog fakulteta. Games-Howellovim testom utvrđena je i značajna razlika između sudionika s Građevinskog fakulteta $(M=2,44) \mathrm{u}$ odnosu na sudionike s Agrobiotehničkog fakulteta $(\mathrm{M}=2,72)$. Rezultati pokazuju da sudionici Agrobiotehničkog fakulteta imaju pozitivnije stavove prema dominantnosti žene u obitelji od sudionika s Građevinskog fakulteta.

Tablica 9. Razlike u stavovima o ulozi žene s obzirom na područje studija sudionika

\begin{tabular}{|c|c|c|c|c|c|c|c|}
\hline Varijable & Fakultet & $\mathbf{N}$ & $\mathbf{M}$ & SD & Min & Max & $\mathbf{F}$ \\
\hline \multirow{5}{*}{$\begin{array}{l}\text { Žena kao majka } \\
\text { i njegovateljica }\end{array}$} & Agrobiotehnički & 94 & 3,21 & 0,58 & 1,29 & 4,29 & \\
\hline & Građevinski & 93 & 3,28 & 0,58 & 1,43 & 4,71 & \\
\hline & Elektrotehnički & 94 & 3,24 & 0,51 & 2 & 4,57 & 1,820 \\
\hline & Filozofski & 94 & 3,10 & 0,053 & 1,43 & 4,29 & \\
\hline & Ukupno & 375 & 3,21 & 0,55 & 1,29 & 4,71 & \\
\hline \multirow{5}{*}{$\begin{array}{l}\text { Žena kao } \\
\text { poslovna osoba }\end{array}$} & Agrobiotehnički & 94 & $2,72 *$ & 0,73 & 1 & 5 & \\
\hline & Građevinski & 93 & $2,44^{*}$ & 0,60 & 1 & 4,20 & \\
\hline & Elektrotehnički & 94 & 2,65 & 0,67 & 1 & 4,80 & $3,067^{*}$ \\
\hline & Filozofski & 94 & 2,62 & 0,59 & 1,20 & 4,40 & \\
\hline & Ukupno & 375 & 2,61 & 0,66 & 1 & 5 & \\
\hline \multirow{5}{*}{$\begin{array}{l}\text { Ravnopravnost } \\
\text { žene }\end{array}$} & Agrobiotehnički & 94 & 4,29 & 0,75 & 1,67 & 5 & \\
\hline & Građevinski & 93 & 4,3728 & 0,71 & 1,67 & 5 & \\
\hline & Elektrotehnički & 94 & $4,13^{*}$ & 0,67 & 2,67 & 5 & $3,911^{* * * * * 5}$ \\
\hline & Filozofski & 94 & $4,45^{*}$ & 0,52 & 2 & 5 & \\
\hline & Ukupno & 375 & 4,31 & 0,68 & 1,67 & 5 & \\
\hline \multirow{5}{*}{$\begin{array}{l}\text { Dominantnost } \\
\text { žene }\end{array}$} & Agrobiotehnički & 94 & $2,72 *$ & 0,73 & 1 & 5 & \\
\hline & Građevinski & 93 & $2,44^{*}$ & 0,60 & 1 & 4,20 & \\
\hline & Elektrotehnički & 94 & 2,65 & 0,67 & 1 & 4,80 & $3,067 \%$ \\
\hline & Filozofski & 94 & 2,62 & 0,59 & 1,20 & 4,40 & \\
\hline & Ukupno & 375 & 2,61 & 0,66 & 1 & 5 & \\
\hline
\end{tabular}

$p<0,05^{*}, p<0,01^{* *}, p<0,001^{* * * *}$

Istraživani su stavovi i o financijskom doprinosu žene u domaćinstvu. Jednosmjernom analizom varijance utvrđena je statistički značajna razlika 
$(\mathrm{p}<0,05)$ u stavu sudionika istraživanja prema ulozi ženi kao majke i domaćice $[\mathrm{F}(2,372)=3,264, \mathrm{p}=, 039]$.

Tablica 10. Stavovi o ženinoj ulozi s obzirom na financijski doprinos

\begin{tabular}{|c|c|c|c|c|c|c|}
\hline Varijable & & Ss & Df & MS & $\mathbf{F}$ & Sig. \\
\hline \multirow{2}{*}{ Žena kao majka i domaćica } & \multirow{2}{*}{$\begin{array}{l}\text { Financijski } \\
\text { doprinos }\end{array}$} & 1,936 & 2 & 0,968 & \multirow{2}{*}{3,264} & \multirow{2}{*}{$0,039^{*}$} \\
\hline & & 110,331 & 372 & 0,297 & & \\
\hline \multirow{2}{*}{ Žena kao poslovna osoba } & \multirow{2}{*}{$\begin{array}{l}\text { Financijski } \\
\text { doprinos }\end{array}$} & 0,029 & 2 & 0,014 & \multirow{2}{*}{0,033} & \multirow{2}{*}{0,968} \\
\hline & & 161,267 & 372 & 0,434 & & \\
\hline \multirow{2}{*}{$\begin{array}{l}\text { Ravnopravnost žene } \\
\text { u obitelji }\end{array}$} & \multirow{2}{*}{$\begin{array}{l}\text { Financijski } \\
\text { doprinos }\end{array}$} & 0,270 & 2 & 0,135 & \multirow{2}{*}{0,293} & \multirow{2}{*}{0,746} \\
\hline & & 171,211 & 372 & 0,460 & & \\
\hline \multirow{2}{*}{$\begin{array}{l}\text { Dominantnost žene } \\
\text { u obitelji }\end{array}$} & \multirow{2}{*}{$\begin{array}{l}\text { Financijski } \\
\text { doprinos }\end{array}$} & 0,029 & 2 & 0,014 & \multirow{2}{*}{0,033} & \multirow{2}{*}{0,968} \\
\hline & & 161,267 & 372 & 0,434 & & \\
\hline
\end{tabular}

$\mathrm{p}<0.05^{*}, \mathrm{p}<0.01^{* * *}, \mathrm{p}<0.001^{* * * *}$

\section{Rasprava}

Rezultati istraživanja pokazuju pozitivan i egalitaran stav sudionika o ulogama žene u obitelji u kojima zagovaraju suvremeno roditeljstvo u kojem nema rodno podijeljenih uloga. Dobiveni rezultati sukladni su prijašnjim istraživanjima u kojem se 97,4 \% sudionika slaže s izjavom da i muškarac i žena moraju pridonositi održavanju kućanstva. ${ }^{36}$ Sudionici ženu u suvremenoj obitelji vide kao poslovnu osobu, a ne samo kao domaćicu. Zaposlenost žene najbolji je način da ona postane slobodna i neovisna tvrdi $72 \%$ sudionika, što je u skladu s prije provedenim istraživanjima. ${ }^{37}$

Istraživanje donosi nove poglede sudionika budućih intelektualaca koji u 86,6 \% tvrde da zaposlenost majke neće ostaviti negativne emocionalne posljedice na dijete predškolske dobi. Ovi rezultati nisu u skladu s prijašnjim istraživanjima u kojima 55,6 \% sudionika tvrdi da dijete u predškolskoj dobi pati kada je njegova majka zaposlena i radi. ${ }^{38}$ Povratak majke na posao u roku od šest mjeseci nakon poroda može imati negativne (manje) učinke na razvoj djeteta, ${ }^{39}$ nije potvrđeno ovim istraživanjem u kojem više od $60 \%$ sudionika tvrdi da je u redu ako se majka nakon poroda odluči ubrzo vratiti na posao. Usporedna istraživanja su rađena prije deset i dvadeset godina pa je moguće zaključiti da su se današnji mladi u pogledima odmaknuli od tadašnjih stavova

\footnotetext{
${ }^{36}$ Usp. Črpić, Bišćan, Muško i žensko između..., 427.

${ }^{37}$ Usp. isto, 430.

${ }^{38}$ Usp. isto, 473.

${ }^{39}$ Usp. Maria C. HUERTA i dr., Early Maternal Employment and Child Development in Five OECD Countries, OECD Social, Employment and Migration Working Papers, OECD Publishing, 2011, 118; https://doi.org/10.1787/5kg5dlmtxhvh-en.
} 
o emocionalnim odnosima majke i djeteta. To je sukladno tvrdnjama u ovom istraživanju da je danas prihvatljivije da se žena odluči na karijeru izvan kuće kojom sebi može omogućiti neovisnost.

Statistički značajne razlike utvrđene su u tvrdnjama prema spolu sudionika u kojima sudionice imaju egalitarnije stavove o ženinim ulogama. Sudionici izražavaju pozitivnije stavove o percepciji žene kao majke i domaćice, što potvrđuju prijašnja inozemna istraživanja. ${ }^{40}$ Promjene se nisu dogodile u pogledima studenata koji su ostali tradicionalni u stavovima o ženinoj ulozi uspoređujući ih s tvrdnjama od prije trideset godina.

T-test je dokazao nepostojanje značajne razlike u stavovima između sudionika koji dolaze s ruralnih područja u odnosu na sudionike urbanih područja. Ovaj rezultat u skladu je s prijašnjim nalazima istraživanja. ${ }^{41}$

Rezultati sugeriraju da sudionici s Agrobiotehničkog fakulteta imaju pozitivnije stavove prema poslovnoj ženi, nego sudionici s Građevinskog fakulteta. Položaj i ravnopravnost žene u obitelji sudionici s Filozofskog fakulteta pozitivnije procjenjuju u odnosu na sudionike s Elektrotehničkog fakulteta. Ovo se može objasniti činjenicom da je većina sudionika s Elektrotehničkog fakulteta muškog spola $(M=82$ i $\check{Z}=12)$, dok su na Filozofskom fakultetu u istraživanju dominirale sudionice ( $M=22$ i $\check{Z}=72$ ). Rezultati su u skladu s rezultatima prijašnjih istraživanja među studentima o rodnim ulogama, gdje dominantni muški smjerovi zauzimaju tradicionalnije stavove prema rodnim ulogama, dok žensko-dominantni smjerovi zauzimaju modernije stavove. ${ }^{42}$ Pozitivniji stavovi sudionika s Filozofskog fakulteta mogu se objasniti činjenicom da su sadržaji studija društvenih i humanističkih znanosti usmjereni na razvoj kritičkog mišljenja, što uključuje i rodna pitanja. ${ }^{43}$ Prema prijašnjim istraživanjima tradicionalan stav prema rodnim ulogama je sve manji što je majka obrazovanija, ${ }^{44}$ dok u ovom istraživanju nisu utvrđene značajne razlike u stavovima sudionika

\footnotetext{
${ }^{40}$ Usp. Judith GIBBSONS, Deborah STILES, Gina SHKODRANI, Adolescents' attitudes toward family and gender roles: An international comparison, Sex Roles, 25 (1991) 11-12, 625-643; doi:10.1007/BF00289568; Črpić, Bišćan, Muško i žensko između...; Irene H. FRIEZE i sur., Gender-Role Attitudes in University Students in the United States, Slovenia, and Croatia, Psychology of Women Quarterly, 27 (2003) 3, 256-261; https://doi.org/10.1111/14716402.00105; Allysa N. BRYANT, Changes in Attitudes Toward Women's Roles: Predicting Gender-Role Traditionalism Among College Students, Sex Roles, 48 (2003) 131-142; https:// doi.org/10.1023/A:1022451205292.

${ }^{41}$ Usp. Hajnalka FENYES, Gender role attitudes among higher education students in a borderland Central-Eastern European region called 'Partium, CEPS Journal, 4 (2014) 2, 49-70.

${ }^{42}$ Usp. isto.

${ }^{43}$ Usp. Pekka RASANEN, Anna T. WILSKA, Finnish Students' Attitudes towards Commercialised Seks, Journal of Youth Studies, 10 (2007) 5, 557-575; https://doi. org/10.1080/13676260701597243.

${ }^{44}$ Usp. Dwayne SMITH, George SELF, The congruence between mothers' and daughters' sexrole attitudes: A research note, Journal Of Marriage And The Family, 42 (1980) 1, 105-109; https://doi.org/10.2307/351938.
} 
s obzirom na obrazovanje majke. ${ }^{45}$ Dobiveni rezultati se mogu objasniti time da su svi sudionici polaznici visokog obrazovanja, a oni su tijekom socijalizacije i procesa obrazovanja izloženi različitim utjecajima i spoznajama koji se mogu razlikovati od onih koje su primili u svom obiteljskom domu, a koji su mogli utjecati na promjene njihovih stavova.

Provedenim istraživanjem zaključujemo da je postavljena hipoteza H1 djelomično potvrđena jer su dobivene razlike u stavovima s obzirom na spol i fakultet koji sudionici pohađaju, ali ne postoje razlike s obzirom na njihovo geografsko porijeklo. Hipoteza $\mathrm{H} 2$ je potvrđena u potpunosti jer je dokazano da sudionici urbanih područja i društvenih znanosti iskazuju pozitivne stavove o ulozi žene u obitelji. Postavljena hipoteza $\mathrm{H} 3$ je djelomično potvrđena jer je dokazano da sudionici Elektrotehničkog fakulteta imaju tradicionalnije stavove prema položaju žene u obitelji, ali sudionici Agrobiotehničkog fakulteta nemaju takove stavove, nego su njihovi stavovi egalitarni, što nije bilo očekivano. Egalitarni stavovi očekivano su potvrđeni kod sudionika koji pohađaju društveno-humanističke studije.

Uzorak istraživanja je prigodan i čine ga studenti s područja istočne Hrvatske što ograničava mogućnost generalizacije svih pokazatelja. Ali je moguća generalizacija stavova sudionika koji potvrđuju da razina obrazovanja i vrste znanstvenih područja studija imaju značajan utjecaj na shvaćanje, vrednovanje i promjenu percepcije uloge žene u suvremenoj obitelji.

\section{Zaključak}

U obiteljima u kojima je žena zaposlena nastaju problemi roditeljskih uloga i društvenih očekivanja. Suvremena žena osjeća dvostruku opterećenost svojom zaposlenošću i obvezama u kućanstvu. Uzorak sudionika ispitivanja obuhvaća studente pa je moguće zaključiti da obrazovanje sve više djeluje na njihove liberalnije stavove. U istraživanju i dalje postoje patrijarhalni stavovi kod muških sudionika koji češće imaju pozitivnije stavove prema ženi majci i njegovateljici. Sudionice istraživanja zauzimaju pozitivnije stavove prema poslovnoj ulozi žene. Moguće je zaključiti da sudionice iskazuju feminizirane stavove vodeći se ravnopravnošću položaja žene u obitelji, zauzimajući se za samostalnost i neovisnost žene, te napuštanjem rodno podijeljenih uloga. Sudionici obaju spolova pohađaju visoka učilišta i u većini tvrde da zaposlenost majke izvan kuće neće ostaviti negativne emocionalne posljedice na djecu predškolske dobi. Istraživanje ukazuje na izmijenjene stavove koji dominiraju posljednjih godina $\mathrm{s}$ naglaskom da su u prijašnjim istraživanjima bili obuhvaćeni sudionici svih

\footnotetext{
${ }^{45}$ Usp. Andreja BARTOLAC, Željka KAMENOV, Olivera PETRAK, Rodne razlike u obiteljskim ulogama, zadovoljstvu i doživljaju pravednosti s obzirom na tradicionalnost stava, Revija za socijalnu politiku, 18 (2011) 2, 175-194; https://doi.org/10.3935/rsp.v18i2.998.
} 
obrazovnih razina, što u našem istraživanju nije bio slučaj. Izmijenjeni stavovi sudionika ukazuju na potrebu daljnjih djelovanja na popularizaciji tih stavova što podrazumijeva uključivanje sadržaja građanskog odgoja na visoka učilišta. Treba razmatrati rodne uloge, humane odnose među spolovima i demokratske stavove o ulogama spolova, ulozi roditeljstva i obiteljskim čimbenicima u odgoju.

\section{Mirko Lukaš" - Lucija Puhanić"** \\ Contemporary Roles of Women in the Family from the Perspective of the Students of Eastern Croatia \\ Summary}

Social changes leave a great impact on the family, it's structure, factors and their family roles. Modern societies are experiencing the expansion of women in the labour market, which is reflected in their position and role in the family. In addition to the traditional role of housewife, women also take on professional engagement. In addition to her financial contribution, she continues to play the role of mother, care for children and the household in the family. The burden of most household chores remained the task of women as in previous generations. This research aimed to examine the attitudes of Eastern Croatian students about the roles of women in the modern family. The research seeks to answer which women's roles are dominant in today's families in relation to the traditional family. 375 students (202 males and 173 females) from the University in Osijek participated in the research. A survey questionnaire was used to conduct the research. Data processing was performed by descriptive statistics, $\mathrm{t}$-tests for independent samples and one-way analysis of variance. The obtained results have the expected attitudes towards the role in regard to gender and field of study. Participants in social, humanities, and agrobiotechnical sciences show more egalitarian attitudes toward women's roles in the family than other participants.

Key words: dominant roles, egalitarian views, employed woman, field of study, independence, traditional attitudes.

(na engl. prev. Matej Lukaš)

\footnotetext{
* Mirko Lukaš, PhD, Assoc. Prof., Faculty of Humanities and Social Sciences in Osijek; Address: Lorenza Jägera 9, HR-31000 Osijek, Croatia; E-mail: mirkolukas64@gmail.com

**ucija Puhanić, Mag. Educ., Srednja škola Isidora Kršnjavoga Našice; Address: Augusta Cesarca 20, HR-31500 Našice, Croatia; E-mail: lpuhanic@outlook.com.
} 